\title{
Control of Rots and Spoilage of Agricultural Products: A Review
}

\author{
S. N. Deshi1 \\ D. L. Wonang ${ }^{2}$ \\ B.S. Dafur ${ }^{3}$ \\ 1 \& 3 Department of Agricultural Science Education, Federal College of Education Pankshin, Plateau State \\ 2 Department of Plant Science and Technology, University of Jos, Plateau State, Nigeria
}

Doi:10.5901/ajis.2014.v3n7p38

\section{Abstract}

The most important losses in agricultural production which involve the greatest costs on the farm economy occur postharvest. It is estimated that worldwide between 10 and 40\% losses of agricultural produce occur postharvest. Losses are more severe in developing than developed nations of the world. Several species of fungi and in some cases bacteria participate in postharvest deterioration and rots of tubers and agro- produce. These include species of Aspergillus, Fusarium, Colletotrichum, Macrophomina, Penicillium and Rhizopus amongst several others. In a bid to control these storage diseases several control techniques including physical, biological, and chemical and in recent times plant-based pesticides are employed. Chemical control has been identified as the most popular and most effective means of controlling plant diseases. However, it is being deemphasized due largely to mammalian toxicity occasioned by chemical residues in crops. This in addition to many other demerits on ecological health and build-up of pathogens' resistance to some of the most effective fungicides have prompted search for alternatives. Recently in plant pathology many tropical plants are being screened for fungitoxic properties. This review presents highlights of the different control techniques for control of myco- induced storage rots of tubers and agricultural products in the tropics.

Keywords: Rots, Postharvest spoilage, Fungitoxicity, Plant-based pesticides.

\section{Introduction}

One of the most pressing problems facing the countries of the third world is food scarcity. It is reported that nearly 1 billion people are challenged by severe hunger in these nations of which $10 \%$ actually die from hunger-related complications. A substantial part of this hunger problem stems from inadequate agricultural storage and produce preservation from microbes-induced spoilages (Salami and Popoola, 2007; Kana et al., 2012). According to Arya (2010), of all losses caused by plant diseases, those that occur after harvest are the most costly.

Rots according to Taiga (2011) result in loss of 7 million MT of yams annually. Rot of yam tubers may be soft, wet or dry and could occur pre- or post-harvest. Pre-harvest rots are due to infection of tubers by soil-borne pathogens. Generally, rotting starts from the field and progressed in storage. Postharvest fungal rots are up to $10 \%$ in yams (Ikotun, 1986). However, recent survey of three agriculturally important yam species in storage (D. cayenensis, Dioscorea rotundata and D. alata) in Umudike Southeast Nigeria, established mean fungi- induced rots ranging between 37.5 and $40 \%$ amongst the species (Ndubuisi, 2010). This may aggravate to 50\% in some instances (Okigbo, 2005; Okigbo et al., 2009b) especially now given the challenge of climate change (Sadiku and Sadiku, 2011). Nahunnaro (2008) pointed out that Rots are exacerbated by high ambient temperatures and relative humidity.

Some workers reported that spoilage organisms produce extra-cellular enzymes such as amylases, celluloses, zylanases, polygalactunases and pectin-methyl esterases which degrade cell wall components of susceptible produce leading in some cases to emission of foul odour and water (Salami and Popoola, 2007; Amadioha, 2012; Oladoye et al., 2013). Hence rots reduce the market value of affected produce, hamper the addition of value to them and prevent produce to complete their roles in the food chain. In a bid to keep these organisms at bay, controls are employed which increase the cost of production. These costs are passed over to the end users of the commodities.

Another very important impact of spoilage and postharvest deterioration by fungal pathogens is the production of various types of mycotoxins on produce such as oil seeds, maize and cereals. Mycotoxins are low molecular weight toxic secondary metabolites from some species of fungi. They are dangerous in minute quantities and present extreme toxicity 
due to their ability to withstand heat (Okigbo, 2004; Shukla et al., 2012). The mycotoxins of most agricultural importance are aflatoxins, fumonisins, ochratoxin A, zearalenone and deoxynivanelol (Bankole and Adebanjo, 2003). According to this source fungal toxin contamination of food products can cause acute or chronic intoxications, leads to reduced life expectancy; exacerbate disease conditions in humans leading to $40 \%$ loss of economic productivity. Mycotoxins are carcinogenic, cytotoxic, hepatotoxic, nephrotoxic and teratotoxic. They affect agricultural economies of developing countries, reducing their produce exportability (Shukla et al., 2012).

According to Bankole and Adebanjo (2003), ear borers such as Mussida sp., Sitophilus zeamais and Carpophilus dimidiatus have been linked with aflatoxin contamination of maize cobs right from the field. These insect pests bore into kernels of grains providing portals for easy entrance and colonization of the affected kernels by mycotoxin organisms. Pre-harvest aflatoxin production in maize is exacerbated by wet weather conditions during crop maturation following insect damage. The risk is high when environmental conditions are characterized by soil moisture stress with elevated temperatures which could crack and rupture testa of grains. In pre-harvest rots of tuber crops, nematodes also have been suggested to play important roles in creating portals of entry to rot inciting organisms. Many nematodes have been implicated in this dimension including species of Meloidogyne, Scutellonema, Helicotylenchus, Rotylenchus and Practylenchus (Okigbo, 2004; Carsky et al., 2010). In the overall, yams infected in the field, rot speedily in storage.

Apart from inclement weather and poor storage conditions of our tropical storage systems, another factor that contributes to rots of produce is inappropriate handling. With the exception of Colletotichum spp. which can penetrate healthy tissues of fresh produce, rot organisms are mainly low-grade fungi, and as such wound requiring and wound assisted (My Agriculture Information Bank, 2013). Improper handling leaves-off bruises on produce during harvesting, transit or storage. Bruises may become contaminated from adherent soils or air-borne propagules which later colonise such abrasions to cause rots (Okigbo, 2004; Okigbo and Nmeka, 2005). This review hence, highlights the different control strategies for control of fungi induced rots of tubers and agro-produce and emphasized the efficacy of plant-derived pesticides in their control.

\section{Different Control Strategies}

In order to meet the food demand challenges of our teeming economies, and to attain sufficiency and security in food production, food production must be matched adequately with their protection from spoilage and rots- inducing organisms during transit or storage (Shukla et al., 2012). In a bid to control these organisms and the deterioration or rots attendant from them, several control techniques have been devised. Some are highlighted below.

\subsection{Good Agronomic Practices, Field Sanitation and Store Hygiene}

According to various workers, rotting usually starts from the field and progresses in storage (Okigbo and Ikediugwu, 2000; Okigbo, 2004). Arya (2010) observed that pre-harvest cultural practices are essential and if well adopted, will considerably reduce postharvest diseases during storage. This source remarked that in fruit orchards for example, collection of rotted fruits, dumping them into deep trenches and covering them with thick layers of soil or burning them away from the orchard will aid in reducing the transmission of the rot pathogens from one fruit to the other. So also the rouging of diseased bunches from the trees. In an evaluation in yams, Okigbo (2004) reported that pre-harvest rots are due to infection of the tubers by soil-borne pathogens. Hence, according to Bankole and Adebanjo (2003) cleaning the field of remains of previous harvest and destroying infested crop residues are basic sanitary measures against rots incitants.

There is need also for early planting that disallows crop maturity from coinciding with periods of peak rain regimes. Such early harvesting has been advocated to reduce the risk of mould build-up and mycotoxin contamination in susceptible produce. Pre- harvest insects and nematode controls have also been identified as essential to good storability of agro-produce as the activities of these organisms have been found to have profound effects on rots development and severities in stored products. While nematodes create entry and infection points on produce through root wounding in the soil, insects do same to grains on ears of corns, rice, wheat etc. and good field control of these organisms reduces the risk of rots of produce in storage (Okigbo, 2004; Bankole and Adebanjo, 2003).

High moisture contents of produce or grains contribute to deterioration of produce in storage by fungal pathogens (Shukla et al., 2012). Rapid drying of grains and other produce from the farm has been emphasized as an important step to avoiding rots of produce. Bankole and Adebanjo (2003) reported that dry grains keep longer, safe from insects and moulds because the water activity required for their growth is not met. Drying harvested maize for instance to $18.5 \%$ 
moisture content within $48 \mathrm{~h}$ after harvesting reduces the risk of mould growth on them. Besides, the factors of insect infestation and high moisture contents in stored products encourage mycotoxins build up on such products. Maize, groundnut and yam chips are mycotoxins-prone.

Some species of fungi have been associated with mycotoxin production in grains. These are Aspergillus, Penicillium, Fusarium, Alternata and Cladosporium. Mycotoxins are toxic to humans and animals. The toxicity of mycotoxins such as aflatoxins and fumonisins stems from their extreme stability to high temperatures; and dangerous nature in minute quantities (Shukla et al., 2012). Presence of deposits of mycotoxins in grains in turn reduces the market value of such agro- products (Bankole and Adebanjo, 2003). The authors reported that disposing heavily damage maize ears from the farm (those with greater than $10 \%$ ear damage) reduce aflatoxin deposit levels in maize. In high rainfall areas such as Southern Nigeria, in addition to sun drying, grains especially maize and melon seeds are spread on the floor and turned occasionally till the produce are dried. They may be stacked on raised platforms under cover to shield them from rains or in some cases dried over fire places.

Another important factor is store condition and hygiene (Shukla et al., 2012). This source remarked that defects in the storage facility lead to moisture absorption by stored products, creating mouldiness and hot-spots. Therefore efforts should be made to prevent moisture migration into grains through leaking roofs and condensation resulting from inadequate store ventilation (Bankole and Adebanjo, 2003). Cleaning of stores properly before loading in the new harvest will not only reduce rots but correlated according to Hell et al. (2000) to reduced aflatoxin deposits in the grains.

\subsection{Thermal and Physical Control}

Curing involves exposing harvested tubers to high temperatures and relative humidity $(\mathrm{RH})$ for a short time usually about $24 \mathrm{~h}$. In the curing process of cassava for example (Okigbo et al., 2009a) reported that the fresh harvested tubers are exposed to temperature range of 25 to $35^{\circ} \mathrm{C}$ and 80 to $90 \% \mathrm{RH}$ for 7 to 14 days. According to Okigbo (2004), curing naturally encourages thickening of the tuber skin. It allows healing of wounds and abrasions sustained during harvesting through surberin formation at wound sites, and subsequent development of periderm or corky layer over the wounds. Consequently, the corky layer callouses-off infective agents and prevents water loss from the wounds. Hot water dips and hot vapour exposures are another means of control. Salami and Popoola (2007) reported the association of B. orzyae, Furisarium redolens, F. oxysporium and Penicillium spp with rot of Irish potato in Ibadan and Jos, Nigeria. According to Agrois (1998), parasitic diseases commonly arise as a result of environment-moderated interchange of metabolites between an invading parasite and the host tissue of plants. Enzymes are known to be the first weapons of attacks selected by pathogens upon contact with compatible host plant tissues. Many plant pathogenic organisms are capable of producing cell wall degrading enzymes such as amylases and celluloses.

Salami and Popoola (2007) found that blanching the tubers in hot water $\left(60^{\circ} \mathrm{C}\right)$ significantly controlled rots induced by these fungi and enhanced their storable period. It could be that this thermal treatment, denatured these cell wall degrading enzymes produced by these pathogens, thereby affecting their arrest and control. According to Arya (2010) postharvest decay of strawberries (Botrytis cinerea) was controlled also by exposure of the fruits to hot humid air at $40^{\circ} \mathrm{C}$ for about $1 \mathrm{~h}$.

Low temperatures have been employed in the treatment and control of rots in fruits, vegetable etc. This has been inferred as causing inactivity of the organism without being able to kill them. The danger with low temperature storage lies in the fact that as soon as favourable conditions prevail, the organisms begin the rot process in the fruits since they were only hibernating. Low temperature storage require hi-tech facilities and constant power supply which may be within reach of resource-rich farmers of Europe and America and not so for their counterparts in Nigeria whose production and storage capabilities are strongly challenged by erratic electric power supply. Despite these short-comings however Okigbo (2004) found that storing yam tubers at 16 to $17^{\circ} \mathrm{C}$ improved their storage life for up to four months. He however, remarked that lower temperature of $<10^{\circ} \mathrm{C}$ is more effective in preserving the tubers against rot organisms; but the attendant chilling damage associated with such temperature is one of the most important deterrents to its industrial applications.

\subsection{Biological Control of Rot Organisms}

Biological control of plant diseases involves the practice whereby the growth, survival and activity of a pathogen is reduced via the agency of any other living organism and with the result that there is reduction in the evidence of the disease caused by the pathogen. According to Okigbo (2004), soil-derived non-pathogenic strains of Bacillus subtilis and Trichoderma viride are potent bio- control agents which controlled postharvest and storage rots of yam tubers. A single 
application of this bio-control agent protected tubers in storage for up to 6 months (Okigbo and Ikediugwu, 2000). In parallel studies, the saprophytic strain of the bacterium Pseudomonas syringe $(L-59-66)$ also satisfactorily controlled the difficult grape rots (B. cinerea) and blue mould of Citrus (P. citrinum) (Arya, 2010). This saprophyte has been developed into a commercial brand (Ecosuinex). B. subtilis showed similar strong fungitoxic activity and has been adopted to control anthracnose of avocado caused by Colletotrichum gloesporoides.

In some instances, research has shown that combining bio-control agents with some derivatives or out-right chemicals increased their activity. According to Arya (2010), nitrogenous and starch compounds (L-aspartigine and Dglucose) used in association with the bio-agent Candida saitiana decreased postharvest rot diseases of fruits while the growth and development of rot organisms on pear was reduced $95 \%$ by synergizing a strain of Penicillium expansum with thiobendazole. In addition to being eco- friendly, the need for repeated spray applications as in synthetic fungicides is unnecessary with biological control agents (Okigbo, 2004). Although the mechanisms of action of these bio-control agents have not been fully explained, competition for space and nutrients, antibiosis, direct parasitism, as well as rapid and effective colonization of wound sites against the invading pathogens has been presumed and suggested for their activity (Okigbo, 2004; Arya, 2010; Suprapta, 2012).

\subsection{Chemical Control of Rots and their Causal Agents in Postharvest Produce}

Synthetic pesticides have long-standing reputation in agriculture. Their use has been credited with enhancing yield of agricultural crops and increasing the returns on investment on farm capital (Bennett, 2005). They are fast-acting biocides producing instant effects on the pathogens; resulting in the arrest of the disease development and spread (Biobank, 2009; Vikhe et al., 2010). Synthetic pesticides have broad spectrum of application in the field, transit or store. For example Okigbo et al. (2009a) remarked that curing and treating cassava tubers with thiobendazole-based chemical compounds have been noted to delay the onset of deterioration of cassava tubers. Similar report has been given also on cocoyam corms and cormels with the same fungicide (Nwachukwu and Osuji, 2008).

Control of rots in yam tubers have been attempted with significant benefits with bleach (sodium hypochlorite), borax, captan and orthiophenylphenate, naphthalene acetic acid, maleic hydrazidine, lime and gin (Okigbo, 2004; Okigbo and Nmeka, 2005). For example, the protectant fungicide captan was found to completely inhibit the germination of spores of the rot-inducing organisms Fusarium moniliforme, Botrydiplodia theobromae and Penicillium sclerotigenum while benlate and thiobendazole arrested both spore germination as well as growth of these pathogenic species.

However, these chemicals are heavy-duty chemicals whose demerits are abundant in science literature (Enyiukwu and Awurum, 2013a). Arya (2010) reported that quick disappearing chemical compounds such as ozone, sulphur dioxide (SO2) and acetic acid in recent times have been evaluated as fumigants for use in postharvest protection of produce especially fruits; to reduce dependence on conventional chemical compounds.

These low-weight chemicals have proved effective in eradicating most rot-inducing organisms in grapes. In addition, gamma and ultraviolent radiations are being explored against postharvest rots causing pathogens. This source noted that UV light has germicidal effects and reduced the activity of PAL and peroxidase enzymes in rot inciting organisms. These advantages notwithstanding, fungicide formulations effective enough to control such postharvest diseases as rot of grapes (B. cinerea) and blue mould of Citrus (P. citrinum) are as yet not found (Arya, 2010). A similar report was issued with regard to some field fungal diseases. Pythium soft rot (P. alphanidermatum), Fusarium and Verticillum wilt diseases were emphasized as difficult to control diseases. They were reported to be not adequately controlled with synthetic pesticides interventions (Knowledge Scotland, 2010).

Synthetic chemicals use in plant protection are being de- emphasized for their toxic residues in crops; which causes death through chronic and acute toxic exposures in mammals (Tripathi and Dubey, 2004; Taiga, 2011). They accumulate in the ecosystem with long degradation periods or may degrade to more toxic forms (Enyiukwu, 2002). This broad spectrum of activity spills into eradicating non-target species such as pollinating bees and butterflies in the ecosystem (Shukla et al., 2012; Enyiukwu and Awurum, 2013a). Apart from these, Okigbo (2004) reported their use restrictions in some countries. In addition, they have been implicated in stimulating development of resistance in 150 pathogenic fungal species. For instance, strains of Colletotrichum spp. (anthracnose) are now known to bei resistant to some of the most effective fungicides such as benomyl, carbendazim and thiophenate-methyl (Pinstrup-Anderson and Panda-lorch, 1994; Enyiukwu and Awurum, 2013a).

The development of resistance to known agricultural pesticides by fungal pathogens in recent years has become a very serious problem in crop production and protection (Tripathi and Dubey, 2004). This phenomenon of resistance has been reported to occur within 7 to 10 years post-introduction of every given agricultural chemical formulated to control 
pathogenic fungal organisms (Oreskes and Conway, 2010). These and many more such as finding new techniques of managing postharvest diseases recalcitrant to synthetic fungicide such as bunch rot of grapes (B. cinearea) and blue mould of Citrus (B. citrinum) gave impetus to search for alternatives (Arya, 2010). One such viable alternative is the use of plant-derived pesticides (Enyinkwu and Awurum, 2011, 2012, 2013b).

The exploitation of natural products such as plant extracts and essential oils as alternative strategy in controlling postharvest fungal rots of tubers, fruits and vegetables have been advocated (Tripathi and Dubey, 2004; Amadioha and Markson, 2007a, b; Shukla, 2012). These plant-based pesticides are reported as cheap, easily available in tropical farming localities of Nigeria, easy to prepare, biodegradable by light components and microbes, systemic and less likely for pathogens to develop resistance against them (Opara and Wokocha, 2008; Opara and Obana, 2010, AdjayeGbenwonyo et al., 2010; Enyiukwu and Awurum, 2013a). Okigbo (2005) suggested that it is important to adopt control practices that are affordable, durable, consistent or integrable with prevailing agricultural practices specific to the farming population of an area. Use of plant-derived pesticides in tropical farming systems of Nigeria met these requirements.

\section{Conclusion}

It is important to adopt disease control practices that will be affordable by the bulk of resource-poor farmers in our part of the world. Such plant protection strategy must be durable, compatible and integrable with the prevailing agricultural practices specific to our people. It is noteworthy therefore, that use of plant-derived pesticides in crop production meets these criteria and hence warrants their exploitation in crop production. Compared to synthetic chemicals extracts of plant origin offer the benefits of pre- and post-infection fungitoxicity and leave no toxic load on produce. This therefore makes them an input of choice particularly in organic farming and in low- input conventional farming systems.

\section{Recommendations}

1. More works need to be done in the area of the phytochemistry of extracts. Plant extracts are complex mixtures of compounds. The facts of one potentiating, inhibiting or competing with others cannot be ruled out. We need to fractionate the extracts to identify, isolate, purify and then characterize the principle(s) responsible for these reported controls.

2. Biotechnology and genetic engineering technologies should be strongly emphasized and adopted in the study of these fungitoxic phyto-metabolites to explore and exploit possibilities of encoding rapidly growing weeds or some saprophytes with the genetic ability to produce these metabolites rather than depending solely on combinatorial chemistry for chemical development.

\section{References}

Adjaye-Gbewonyo D, Quaye EC, Wubah D.A, (2010). The effects of extracts of Piper guineense seed on insect pest damage to cowpea. $J$ Young Investigators, 20(1):264-256.

Agrois G.N, (1998). Plant Pathology (Edition 3). Academic Press INC., New York. 703pp.

Amadioha A.C., (2012). Reducing food losses through sustainable methods of plantdisease management: an imperative for actualization of food security in Nigeria. A paper presented at the 13th inaugural lecture MOUAU, June, 2012

Amadioha A.C, and Markson A.A, (2007a). Postharvest control of cassava tuber rot caused by Botrydiplodia acerina using extracts of plant origin.Arch Phytopathol,40(5):359-366.

Amadioha A.C, and Markson A.A, (2007b). Control of storage rot of cassava tuber caused by Rhizopus oryzae using some plant extracts. Arch Phytopathol, 40(6):381-388.

Arya, A. (2010). Recent advances in the management of plant pathogens: Botanicalsin the fungal pest management. In: Management of fungal plant pathogens.

Bankole S.A, Adebanjo, A. (2003). Mycotoxins in food in West Africa: Currentsituation and possibilities of controlling it. Afr J Biotechnol, 2(9):254-263.

Bennett, D. (2005). Farm Press - New study shows the benefits of fungicides use. www.westernfarmpress.com/new=study-shows. Retrieved Oct. 12, 2012.

Biobank, (2009).Farming methods comparison. www.omz.jp/?page_id=271 Retrieved May 9. 2010.

Carsky, R. Asiedu, R. And Cornet D, (2010). Review of soil fertility management for yam- based systems in West Africa. Afr J Root Tuber Crop, 8(2):1-17.

Enyiukwu, D.N., and Awurum, A.N., (2011). Effects of phytochemicals from Carica papaya roots and 4(20):55-59.

Enyiukwu, D.N., and Awurum, A.N., (2012). Comparative fungitoxicity of benomyl andextracts of Carica papaya roots and seeds and Piper guineense seeds on Colletotrichum destrucivum O'Gara.Co nt J Biol Sci, 6(1):38-42. 
Enyiukwu, D.N, and Awurum, A.N., (2013). Fungitoxic principles and antifungal activityof extracts from Carica papaya and Piper guineense on Colletotrichum destructivum. Cont J Biol Sci, 7(1):29-36.

Enyiukwu, D.N., and Awurum, A.N., (2013). Fungitoxic effects of Carica papaya andPiper guineense extracts against Colletotrichumdestructivum in the glasshouse. Cont J Agric Sci, 7(1):23-28.

Gupta, R., Khokhar M.K, and Lai R, (2012).Management of black mould of onion.J. Plant Pathol Microbiol, 3(5):3-5.

Hell, K., Cardwell, K.F., Setamou, M. and Poehling HM, (2000). The influences of storage practices on aflatoxin contamination of maize in four agroecological zones of Benin, West Africa.J Stored Prod Res, 36:365-382.

Kana, H.A., Aliyu, I.A., Chammang, H.B. (2012).Review on neglected and underutilized root and tuber crops as food security in achieving the millennium development goals in Nigeria.J Agric Vet Sci, 4:27-33.

My Agriculture Information Bank, (2013). Microbial losses in fruits and vegetables. In:Nature and causes of deterioration in fruits and vegetables.www.agriinfo.in/defalt.aaspx?page=topic\&spuperid=2\&topicid=1429 Retrieved October 28, 2013.

Okigbo, R.N., Putheti, R., and Achusi, C.T., (2009a). Post-harvest deterioration ofcassava and its control using extracts of Azadirachta indica and Afromoniummeleguata. E-J Chem, 6(4):1274-1280.

Okigbo, R.N., (2004). A review of biological control methods for postharvest yams(Dioscorea spp.) in storage in South Eastern Nigeria.KMITL Sci Technol J, 4(1):207-215.

Okigbo, R.N., (2005). Biological control of postharvest fungal rot of yams (Dioscorea spp.) with Bacillus subtilis. Mycopathologica, 159:307-314.

Okigbo, R.N., Anuagasi, C.L., and Amadi, J.E., (2009b). Advances in selected medicinal and aromatic plants indigenous to Africa.J Med Plant Res, 3(2):86-95.

Okigbo, R.N., and Ikediugwu, F.E.O., (2000). Studies in the biological control of postharvest rot of yams (Dioscorea rotundata) with Trichoderma viride. JPhytopathol, 148:331-335

Okigbo. R.N., and Nmeka, I.A., (2005). Control of yam tuber rot with leaf extracts of Xylopia aethiopica and zingiber officinale. Afr J Biotechnol, 4(8):804-807.

Okigbo, R.N., and Nwakammah, P.T., (2005). Biodegration of white yam (Dioscorearotundata) and water yam (Dioscorea alata) slices dried under different conditions. KMITL Sci Technol J, 5(3):1-10.

Oladoye, C.O., Olaoye, O.A., Cornnerton, I.F., (2013). Isolation and identification of bacteria associated with spoilage of sweet potatoes during postharvest storage.Int J Agric Food Sci, 3(1):10-15.

Opara, E.U., and Obana, F.T. (2010).Performance of some plant extracts and pesticidesin the control of bacterial spot disease of Solanium.Medwell Agric J, 5(2):45-49.

Opara, E.U., and Wokocha, R.C. (2008). Efficacy of some plant extracts on the in vitro and invivo control of Xanthomonas campestrispv vesicatoria. Medwell AgricJ, 3(3):163-170.

Oreskes, N., and Conway, E.M. (2010). Denial rides again; the revisionist attack onRachelCarson. In: Merchants of doubt. NY, Bloomsbury. pp. 216- 235

Pinstrup-Anderson, P. and Panda-lorch, R. (1994).Alleviating poverty, intensifyingagriculture and effectively managing natural resources. A Food, Agriculture and Environment discussion paper Washington DC 20:13-14.

Sadiku, N.A. and Sadiku, I.B.S., (2011). Indigenous efforts by African farmers in ensuring sustainability in agricultural productivity in the face changing climate: A proceeding of the Environmental Management Conference, FUNAAB,Nigeria, 2011.

Salami, O.A. and Popoola, O.O., (2007).Thermal control of some postharvest rotpathogens of Irish potato (Solanum tuberosum L.).J Agric Sci, 52(1):17-31.

Shukla, A.M., Yadav, R.S., Shashi, S.K., Dikshit, A., (2012). Use of plant metabolitesas an effective source for the management of postharvest fungal pest: Areview.Int J Curr Discoveries Innovations, 1(1): 33-45.

Suprapta, D.N. (2012). Potentials of microbial antagonist as biocontrol agents against plant fungal pathogens.J ISSAAS 18(2):1-8.

Taiga, A., (2011). Comparative studies of the efficacy of some selected Fungicidalaqueous plant extracts on Yam tuber dry rot disease. Ann Biol Res, 2(2): 332-336.

Tripathi, P. and Dubey, A.K., (2004). Exploitation of natural plant products as analternative strategy for control of postharvest fungal rotting of fruits and vegetables.Postharvest Biol Tech, 32(3):235-245. 